\title{
NEW PAULOMYCINS PRODUCED BY STREPTOMYCES PAULUS
}

\author{
A. D. Argoudelis, L. Baczynskyj, W. J. HaAk, W. M. KnOlL, \\ S. A. Mizsak and F. B. Shilliday \\ The Upjohn Company, \\ Kalamazoo, Michigan 49001, U.S.A.
}

(Received for publication August 17, 1987)

\begin{abstract}
Paulomycin $\mathrm{A}_{2} \quad\left(\mathrm{C}_{34} \mathrm{H}_{48} \mathrm{~N}_{2} \mathrm{O}_{17} \mathrm{~S}\right)$, paulomycin $\mathrm{C} \quad\left(\mathrm{C}_{32} \mathrm{H}_{42} \mathrm{~N}_{2} \mathrm{O}_{17} \mathrm{~S}\right)$, paulomycin $\mathrm{D}$ $\left(\mathrm{C}_{31} \mathrm{H}_{40} \mathrm{~N}_{2} \mathrm{O}_{17} \mathrm{~S}\right)$, paulomycin $\mathrm{E}\left(\mathrm{C}_{29} \mathrm{H}_{30} \mathrm{~N}_{2} \mathrm{O}_{10} \mathrm{~S}\right)$ and paulomycin $\mathrm{F}\left(\mathrm{C}_{29} \mathrm{H}_{38} \mathrm{~N}_{2} \mathrm{O}_{18} \mathrm{~S}\right)$ have been isolated from fermentations of Streptomyces paulus strain 273. The structure of these compounds was determined using NMR and mass spectroscopic techniques. The new paulomycins, like paulomycins $A$ and $B$ (J. Antibiotics 35: 285 294, 1982) are highly active mainly against Gram-positive organisms.
\end{abstract}

The production of the paulomycin complex by Streptomyces paulus strain 273 and the isolation and separation of paulomycins $\mathrm{A}$ and $\mathrm{B}$, the main components of the mixture, were reported by ARGoudeuIs and his co-workers. ${ }^{1)}$ This paper describes the isolation, characterization and structure of several bioactive minor components produced by $S$. paulus. The biological properties of these new paulomycins, designated paulomycins $\mathrm{A}_{2}, \mathrm{C}, \mathrm{D}, \mathrm{E}$ and $\mathrm{F}$ are also briefly discussed.

\section{Experimental}

Assay and Testing Procedures

Antibiotic production and purification was measured by a microbiological disc-plate assay procedure with Micrococcus lutels as the assay organism.

\section{TLC Procedures}

The production of paulomycins was followed by TLC on Silica gel G using chloroform - ethanol water $(25: 30: 5)$ or chloroform-MeOH $(90: 10)$ as the solvent system. Paulomycins were separated by TLC using Brinkman's cellulose-coated plates and $\mathrm{pH} 7.0$ phosphate buffer as the solvent system. The antibiotics were detected by bioautography on $M$. luteus seeded trays.

Spectroscopic Methods

UV spectra were obtained in MeOH using a Perkin-Elmer Lambda 7 spectrophotometer, IR spectra were run in Nujol mull using a Digilab FTS-ISE spectrometer. ${ }^{1} \mathrm{H}$ NMR spectra were recorded on a Varian XL-200 spectrometer operating at $200 \mathrm{MHz}$. Solutions $(c a .0 .4 \mathrm{ml}, c a .0 .25 \mathrm{M})$ of the compounds in deuterated chloroform or acetone were used. ${ }^{13} \mathrm{C}$ NMR spectra were recorded on a Varian CFT-20 spectrometer operating at $20.0 \mathrm{MHz} .{ }^{1} \mathrm{H}$ and ${ }^{13} \mathrm{C}$ NMR chemical shifts are reported as ppm relative to TMS. Negative ion MS were obtained on a V.G. Analytical ZAB-2F high resolution mass spectrometer using a fast atom bombardment (FAB) source. Bombarding gas, xenon, accelerating voltage $7.0 \mathrm{Kev}$; matrix, tetraethylene glycol (Aldrich Chemical Co., Milwaukee, Wisconsin, U.S.A.).

\section{Analytical HPLC}

All HPLC was carried out with a Varian Model 5560 (Varian Instruments, Sugar Land, Texas, U.S.A.) instrument equipped with a LKB Rapid Spectral Detector (LKB, Broma, Sweden). A Zorbax C-8 $25 \mathrm{~cm} \times 4.6 \mathrm{~mm}$ stainless steel column packed with $\mathrm{C}_{8}(6 \mu \mathrm{m})$ reverse phase silica was used. In most of the cases, the mobile phase consisted of a gradient of solvent $\mathrm{A}$ to $\mathrm{B}$; flow rate 1.5 
$\mathrm{ml} /$ minute. Solvent A consisted of $0.05 \mathrm{~m}$ phosphate buffer ( $\mathrm{pH} 5.5$ ) - acetonitrile - tetrahydrofuran $(80: 20: 20$ ). Solvent B consisted of $0.05 \mathrm{M}$ phosphate buffer ( $\mathrm{pH} 5.5$ ) - acetonitrile - tetrahydrofuran $(40: 30: 30)$. A $10-\mu 1$ sample was usually injected.

\section{Fermentation Conditions}

The fermentation conditions, used for the production of the paulomycin complex by $S$. paulus strain 273 (UC 5142), were identical to those described by MARshall et al. ${ }^{2)}$ Amberlite XAD-2 resin ( 150 liters per 5,000 liters fermentation) was added into the fermentor. Bioassays indicated that at harvest time (120 hours after inoculation) most of the bioactive components produced by $S$. paulus were adsorbed on the resin.

\section{Isolation of Antibiotics Produced by S. paulus}

\section{Extraction with Ethyl Acetate, Isolation of Crude Crystals of Paulomycins}

The fermentation broth ( $c a .5,000$ liters) was adjusted to $\mathrm{pH} 4.5$ with aqueous sulfuric acid and then passed over a large vibrating screen in order to remove the Amberlite XAD-2 resin. The resin was slurried in 100 liters of water and screened off on the vibrating screen. The washed resin was packed in a column, washed with 100 liters of cyclohexane - methylene chloride $(4: 1)$ mixture and then eluted with 1,400 liters of ethyl acetate. The ethyl acetate eluate was concentrated to dryness. The residue was triturated twice with $n$-heptane and then crystallized from methylene chloride. The crude crystalline preparation obtained $(625 \mathrm{~g})$ was dissolved in 3.2 liters of ethyl acetate. The solution was mixed with $31 \mathrm{~g}$ of filter aid and $31 \mathrm{~g}$ of Darco G-60 and stirred for 1 hour. The mixture was then filtered over filter aid and the filtrate was mixed with 3.2 liters of $n$-hexane. The cloudy solution, stored at $5^{\circ} \mathrm{C}$ for 24 hours, yielded $386 \mathrm{~g}$ of crystalline needles. This material was found by HPLC to be a mixture of paulomycins $\mathrm{A}$ and $\mathrm{B}$. The mother liquors concentrated to dryness yielded $c a .200 \mathrm{~g}$ of material enriched in bioactive components other than paulomycins A and B. This material was used for the isolation of paulomycins $\mathrm{A}_{2}, \mathrm{C}, \mathrm{D}, \mathrm{E}$ and $\mathrm{F}$ as discussed below.

\section{Isolation of Paulomycin $\mathrm{A}_{2}$, Partition Chromatography}

Six hundred $\mathrm{g}$ of Dicalite 4200 was slurried with $2,800 \mathrm{ml}$ of upper phase and $200 \mathrm{ml}$ of lower phase of the solvent system consisting of dioxane - cyclohexane - $0.1 \mathrm{M}$ phosphate buffer (pH 7.0) $(35: 68: 8)$. The slurry was then poured into a column and packed to a constant height. The starting material, $3.0 \mathrm{~g}$ of the crude mixture of paulomycins obtained as described above, was dissolved in $15 \mathrm{ml}$ of lower phase and $10 \mathrm{ml}$ of upper phase, mixed with $15 \mathrm{~g}$ of Dicalite and added on the top of the column.

The column was eluted with the upper phase. Eluate fractions containing, by HPLC, paulomycin $\mathrm{A}_{2}$ were combined and concentrated to dryness to yield $40 \mathrm{mg}$ of crystalline paulomycin $\mathrm{A}_{2}$ which was recrystallized from chloroform-ether. Characterization of this material is described later in this manuscript.

\section{Separation of "Polar Paulomycins" from Paulomycins A, $\mathrm{A}_{2}$ and B, Preparative HPLC}

Two Waters C-18 reverse phase silica packed columns, attached to a Waters Prep 500A instrument, were equilibrated with the mobile phase consisting of acetonitrile $-0.01 \mathrm{M}$ phosphate buffer (pH 5.5) (1:1). Forty $\mathrm{g}$ of the crude paulomycin, isolated as described above, was dissolved in $400 \mathrm{ml}$ of the mobile phase and the solution was injected into the first column of the system. The chromatography was run with a flow rate of $100 \mathrm{ml} /$ minute using the above mobile system and followed by a UV detector operating at 275 and $320 \mathrm{~nm}$. In addition, selected fractions were analyzed by TLC using $\mathrm{KC}-18$ reverse phase silica plates and acetonitrile $-\mathrm{MeOH}-0.01 \mathrm{~m}$ phosphate buffer (pH 5.5) $(1: 1: 1)$ as the mobile phase. Fractions containing the "polar paulomycins" were combined and the solution was extracted twice with $50 \%$ of its volume of methylene chloride. The methylene chloride extracts were concentrated to dryness to give $9.0 \mathrm{~g}$ of material containing "polar paulomycins" only. A total of $108 \mathrm{~g}$ of a mixture of "polar paulomycins" was obtained from purification of $480 \mathrm{~g}$

t The term "polar paulomycins" has been used to designate collectively all the new paulomycins and paulomycin-related metabolites with HPLC retention times (RT) lower than the RT of paulomycin B. Paulomycin $A_{2}$, which has $R T$ higher than that of paulomycin $B$, is not included in this group. 
of the crude paulomycin mixture.

Separation of "Polar Paulomycins", Preparative HPLC

The conditions used were identical to those described above with the exception that the mobile phase consisted of acetonitrile $-0.01 \mathrm{M}$ phosphate buffer $(\mathrm{pH} 5.5)(45: 55)$. The starting material, $10.0 \mathrm{~g}$ of the mixture of "polar paulomycins" obtained as described above was dissolved in $400 \mathrm{ml}$ of the mobile phase and injected into the first column of the system. Collected fractions, analyzed by UV and analytical HPLC, were treated as follows.

Four pools were made from fractions containing materials with retention times similar to those of paulomycins C, D, E, and F, respectively. Each pool was extracted with $15 \%$ of its volume of methylene chloride. The extracts, dried over sodium sulfate, were concentrated to dryness. A total of 10 runs were made using conditions identical to those discussed above. Purified paulomycin C, $13.5 \mathrm{~g}$; paulomycin $\mathrm{D}, 38.1 \mathrm{~g}$; paulomycin $\mathrm{E}, 28.8 \mathrm{~g}$; and paulomycin $\mathrm{F}, 4.98 \mathrm{~g}$ were obtained by combination of the appropriate preparations.

\section{Isolation of Pure Paulomycins C, D, E, and F, Preparative HPLC}

Purified paulomycins $\mathrm{C}, \mathrm{D}, \mathrm{E}$ and $\mathrm{F}$ were used as the starting materials in preparative HPLC's using conditions identical to those described earlier with the exception that the following mobile phases were used:

1) For purification of paulomycin C: THF - $0.1 \mathrm{~m}$ phosphate buffer (pH 5.5) (45:55).

2) For purification of paulomycin D: THF - acetonitrile - 0.1 M phosphate buffer (pH 5.5) $(3: 1: 1)$.

3) For purification of paulomycin E: Acetonitrile - 0.1 m phosphate buffer ( $\mathrm{pH} 5.5)(40: 60)$.

4) For purification of paulomycin $\mathrm{F}$ : THF - $0.05 \mathrm{M}$ phosphate buffer ( $\mathrm{pH} 5.5)(35: 65)$.

Fractions obtained during the chromatographies were examined by analytical HPLC, UV and bioactivity. Appropriate pools were made and these solutions were extracted with $15 \sim 20 \%$ of their volume of methylene chloride. The extracts were dried over sodium sulfate and concentrated to dryness. The residues were dissolved in acetone and the solutions were mixed with cyclohexane. Precipitated pure paulomycins $\mathrm{C}, \mathrm{D}, \mathrm{E}$ and $\mathrm{F}$ were isolated by filtration and dried. Characterization of these materials is described in the next section (Results and Discussion).

\section{Results and Discussion}

As reported earlier, ${ }^{1)}$ S. paulus strain 273 produces paulomycin, a mixture of chemically related antibiotics, when grown either on agar or in a submerged culture. The isolation of the paulomycin mixture was followed with bioassays and TLC on silica gel plates using chloroform - ethanol - water $(25: 30: 5)$ as the mobile phase. The paulomycin complex appeared as one zone of bioactivity (Rf 0.8 ) when TLC were developed by bioautography on M. luteus. However, the paulomycin components were separated by TLC on cellulose sheets. Six zones of bicactivity were detected and designated as paulomycin $\mathrm{A}(\mathrm{Rf} 0.14)$, paulomycin $\mathrm{B}(\mathrm{Rf}$ $0.32)$, paulomycin $C(\operatorname{Rf} 0.43)$, paulomycin $D(\operatorname{Rf}$ $0.58)$, paulomycin $\mathrm{E}(\mathrm{Rf} 0.77$ ) and paulomycin $\mathrm{F}$ (Rf 0.88) (Fig. 1). Paulomycin $\mathrm{A}_{2}$ could not be separated from paulomycin $A$ in this TLC system. However, all paulomycins A, A, B, C, D, $\mathrm{E}$ and $\mathrm{F}$ could be separated by analytical HPLC. Detection at $320 \mathrm{~nm}$ gave excellent sensitivity for the various paulomycins while reducing to a minimum the appearance of interfering sub-

Fig. 1. TLC ${ }^{\mathrm{a}}$ of paulomycins $\mathrm{A}, \mathrm{A}_{2}, \mathrm{~B}, \mathrm{C}, \mathrm{D}, \mathrm{E}$ and $\mathrm{F}$.

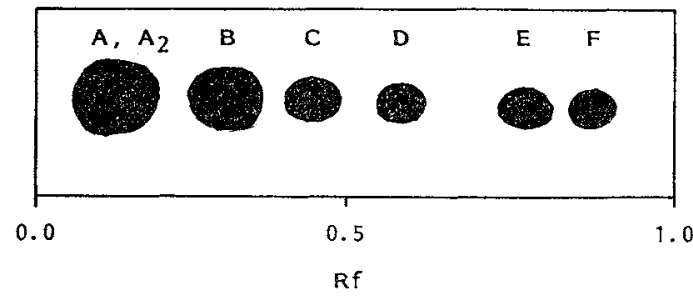

a Cellulose (Polygram CEL 300) pre-coated sheets; $0.1 \mathrm{M}$ phosphate buffer (pH 7.0). Antibiotics were detected by bioautography on Micrococcus luteus seeded agar. 
Fig. 2. HPLC of paulomycins $A, A_{2}, B, C, D, E$ and $F .{ }^{2}$

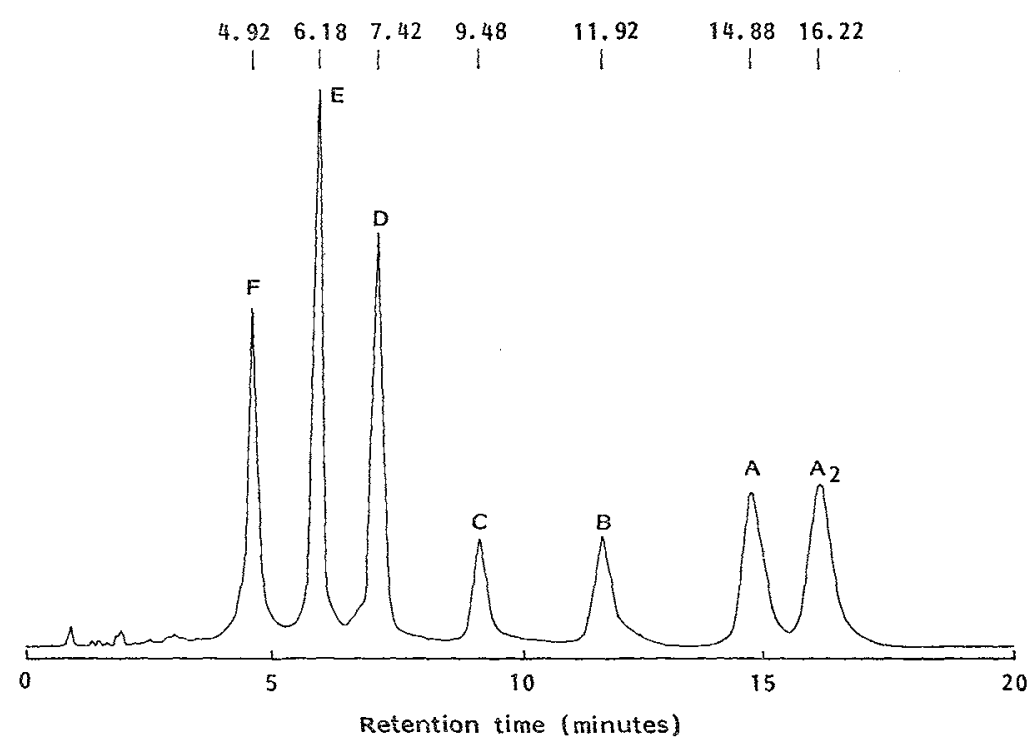

Conditions: Zorbax C-18, $4.1 \times 25 \mathrm{~cm}$ reverse phase silica column. Mobile phase, water - THF acetonitrile $(3: 1: 1)$ containing $0.2 \%$ glacial acetic acid. Detection at $320 \mathrm{~nm}$.

a Numbers at the top of the figure indicate retention times of the individual paulomycins.

stances. An HPLC separation of paulomycins $A, A_{2}, B, C, D, E$ and $F$ is shown in Fig. 2.

Isolation of Paulomycins

Fermentations of $S$. paulus were run in the presence of Amberlite XAD-2. Under these conditions, most of the paulomycins produced were adsorbed on the resin which, at harvest time, was separated from the mycelia by passing over a large vibrating screen. Paulomycins $A, A_{2}, B, C, D, E$ and $F$ were eluted from the resin by ethyl acetate which was concentrated to dryness. The residue was triturated with $n$-heptane then crystallized from methylene chloride. The crude crystals were recrystallized from ethyl acetate - $n$-hexane to yield a crystalline mixture of paulomycins $\mathrm{A}$ and $\mathrm{B}$. The mother liquors, concentrated to dryness, yielded material enriched in paulomycins $A_{2}, C, D, E$ and $F$.

Pure paulomycin $A_{2}$ was obtained by partition chromatography on Dicalite 4200 using dioxane cyclohexane $-0.1 \mathrm{M}$ phosphate buffer (pH 7.0) as the mobile phase. Pure paulomycins $\mathrm{C}, \mathrm{D}, \mathrm{E}$ and $F$ were obtained by repeated preparative HPLC's using a Waters $500 \mathrm{~A}$ preparative system and Waters $\mathrm{C}-18$ reverse phase silica columns. The mobile phases varied depending on the nature of the paulomycin under purification. These separations are detailed in the Experimental part of this manuscript.

\section{Characterization of Paulomycins $A_{2}, C, D, E$ and $F$}

Paulomycin $\mathrm{A}_{2}$ has been isolated as a crystalline colorless (needles) solid, while paulomycins $\mathrm{C}$, $D, E$ and $F$ were obtained as amorphous colorless compounds. All paulomycins are readily soluble in chloroform, methylene chloride, lower alcohols, ethyl and butyl acetates, acetone and most other organic solvents. The antibiotics are less soluble in ether and water and quite insoluble in saturated hydrocarbon solvents.

The physical and chemical properties of paulomycins $A_{2}, C, D, E$ and $F$ are listed in Table 1. All 
Table 1. Physical and chemical properties of paulomycins $A_{2}, C, D, E$ and $F$.

\begin{tabular}{|c|c|c|c|c|c|}
\hline & Paulomycin $\mathrm{A}_{2}$ & Paulomycin C & Paulomycin D & Paulomycin E & Paulomycin F \\
\hline $\begin{array}{l}\text { Molecular formula }{ }^{\mathrm{a}} \\
\mathrm{MW}^{\mathrm{a}}(\mathrm{m} / \mathrm{z})\end{array}$ & $\mathrm{C}_{34} \mathrm{H}_{40} \mathrm{~N}_{2} \mathrm{O}_{17} \mathrm{~S}$ & $\mathrm{C}_{32} \mathrm{H}_{42} \mathrm{~N}_{2} \mathrm{O}_{17} \mathrm{~S}$ & $\mathrm{C}_{31} \mathrm{H}_{40} \mathrm{~N}_{2} \mathrm{O}_{17} \mathrm{~S}$ & $\mathrm{C}_{29} \mathrm{H}_{36} \mathrm{~N}_{2} \mathrm{O}_{18} \mathrm{~S}$ & $\mathrm{C}_{29} \mathrm{H}_{38} \mathrm{~N}_{2} \mathrm{O}_{18} \mathrm{~S}$ \\
\hline Found: & 786.2522 & 758.2210 & 744.2048 & 700.1787 & 702.1935 \\
\hline Calcd: & 786.2517 & 758.2204 & 744.2047 & 700.1785 & 702.1942 \\
\hline $\operatorname{MP}\left({ }^{\circ} \mathrm{C}, \mathrm{dec}\right)$ & $90 \sim 105$ & $100 \sim 110$ & $130 \sim 140$ & $120 \sim 160$ & $114 \sim 130$ \\
\hline$[\alpha]_{\mathrm{D}}^{25}\left(\mathrm{CHCl}_{3}\right)$ & $+25^{\circ}(c 0.28)$ & $+20^{\circ}(c 0.51)$ & $+18^{\circ}(c 0.98)$ & $+24^{\circ}(c 0.25)$ & $+21^{\circ}(c 0.23)$ \\
\hline$[\alpha]_{D}^{25}(\mathrm{MeOH})$ & $-23^{\circ}(c 0.4)$ & $-28^{\circ}(c 0.41)$ & $-36^{\circ}(c 1.0)$ & $-27^{\circ}(c 0.68)$ & $-28^{\circ}(c 0.51)$ \\
\hline $\mathrm{UV} \lambda_{\mathrm{max}}^{\mathrm{MeOH}}(\varepsilon)$ & $\begin{array}{l}237(14,650), \\
277(9,500), \\
321(8,500)\end{array}$ & $\begin{array}{l}237(14,650), \\
277(10,300), \\
321(7,850)\end{array}$ & $\begin{array}{l}237(14,740) \\
275(10,930) \\
321(8,130)\end{array}$ & $\begin{array}{l}240(13,500), \\
276(9,200), \\
322(8,950)\end{array}$ & $\begin{array}{l}238(14,000), \\
276(9,170), \\
321(8,170)\end{array}$ \\
\hline IR (Nujol, $\mathrm{cm}^{-1}$ ) & $\begin{array}{l}3375,3233 \\
2898,2043, \\
1735,1699\end{array}$ & $\begin{array}{l}3375,3233 \\
2898,2043 \\
1735,1699\end{array}$ & $\begin{array}{l}3374,3234 \\
2994,2043 \\
1735,1700\end{array}$ & $\begin{array}{l}3382,3234 \\
2959,2043 \\
1736,1707\end{array}$ & $\begin{array}{l}3379,3234 \\
2954,2043 \\
1736,1698\end{array}$ \\
\hline
\end{tabular}

a By high resolution negative ion FAB-MS.

Fig. 3. IR spectrum of paulomycin D (Nujol mull).

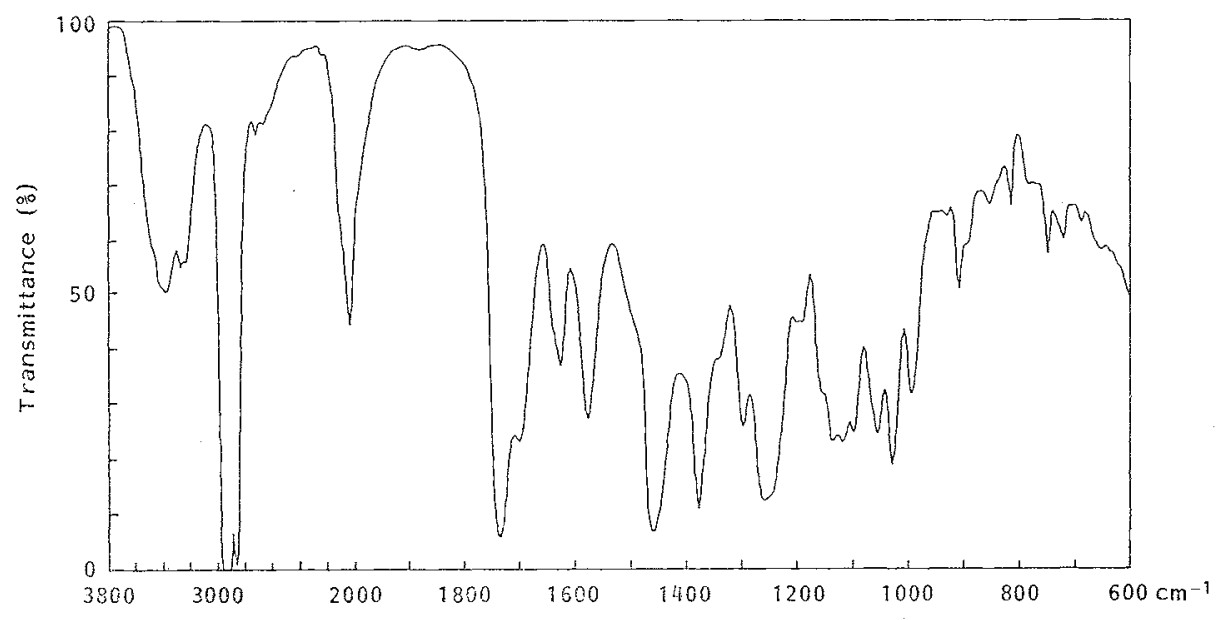

antibiotics melt with decomposition over a broad range of temperature; they are dextrorotatory when the specific rotation was determined in chloroform and levorotatory when methanol was used as the solvent. The molecular formulas and molecular weights were determined by negative ion high resolution MS. The IR spectra of paulomycins $A_{2}, C, D, E$, and $F$, like those of paulomycins $A$ and $\mathbb{B}$ are nearly identical and are characterized by a strong absorption band at $2043 \mathrm{~cm}^{-1}$ attributable to an isothiocyanate group. ${ }^{2}$ The IR spectra which show the presence of carbonyl groups at ca. 1735 and 1700
Fig. 4. UV spectrum of paulomycin D (in MeOH).

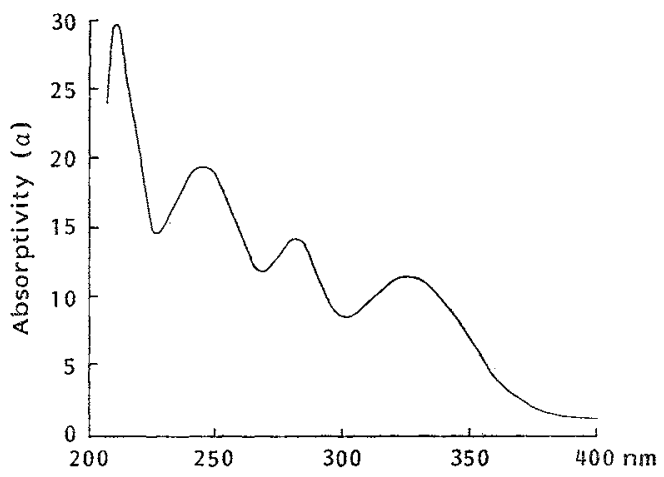


Fig. 5. Negative ion FAB-MS of a mixture of paulomycins A and B.

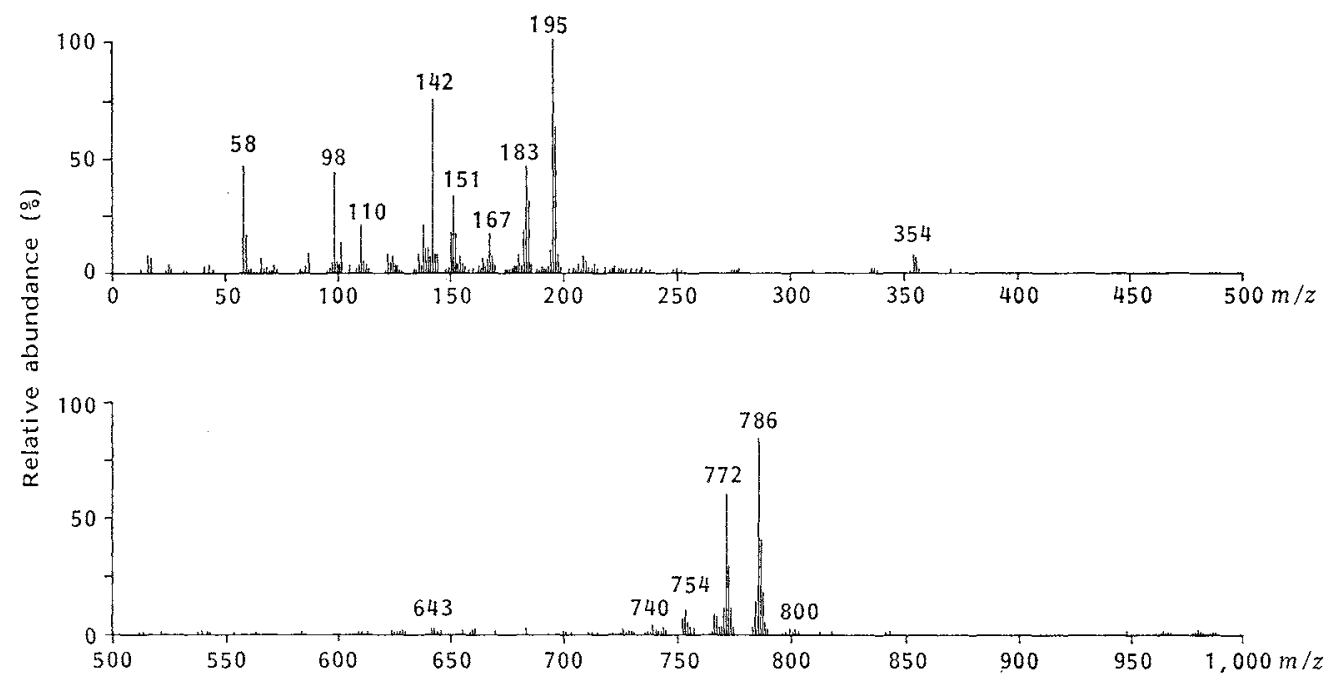

$\mathrm{cm}^{-1}$ cannot be used for differentiation of these antibiotics. The UV spectra of paulomycins $A_{2}, C$, $\mathrm{D}, \mathrm{E}$ and $\mathrm{F}$ are identical to the UV spectra of paulomycins $\mathrm{A}$ and $\mathrm{B}^{1)}$ and contain three peaks at $c a$. 236, 276 and $321 \mathrm{~nm}$. The maximum at $321 \mathrm{~nm}$ has been extremely useful in the isolation work on these antibiotics. The IR and UV spectra of paulomycin D are shown in Figs. 3 and 4 as representative examples of this class of antibiotics. A list of the chemical shifts of carbons, observed in the ${ }^{13} \mathrm{C}$ NMR spectra of paulomycins $A, A_{2}, B, C, D, E$ and $F$ is presented in Table 2. The ${ }^{1} \mathrm{H}$ NMR spectra of paulomycins $\mathrm{A}_{2}, \mathrm{C}, \mathrm{D}, \mathrm{E}$ and $\mathrm{F}$ are similar to those of paulomycins $\mathrm{A}$ and $\mathrm{B}{ }^{1)}$ Table 3 presents selected absorptions, observed in the ${ }^{1} \mathrm{H}$ NMR spectra of paulomycins $\mathrm{A}, \mathrm{A}_{2}, \mathrm{~B}, \mathrm{C}, \mathrm{D}, \mathrm{E}$ and $\mathrm{F}$ due to basic features of these antibiotics. All paulomycins $\left(A, A_{2}, B, C, D, E\right.$ and $\left.F\right)$ gave negative ion FAB-MS which were almost identical at the low mass (below $m / z 360$ ) area of the spectra. Table 4 presents major ions which are common to all paulomycins. These ions, obtained by fragmentation of paulomycins A and B were mass measured to ions of the matrix (tetraethylene glycol). Structural assignments to these ions are presented in Fig. 7. Intense molecular ion peaks and peaks corresponding to M-18 were observed in the negative ion FAB-MS of all paulomycins. The molecular ion peak is often one of the most abundant ions in the spectrum. Thus a simple inspection of the molecular ion region often reveals the purity of a given preparation and this allows a rapid detection of the impurity present. In the case of a mixture of paulomycins, i.e. paulomycins A and B, it allows us to determine the proportion of each of the components in a given lot by measuring the abundances of the molecular ions $\left(\mathrm{M}^{-}\right)$at $m / z 772$ and 786. An example of a spectrum of such a mixture is shown in Fig. 5. Here the abundances of the two molecular ions were $m / z 84.1$ and 59.6. Thus the ratio of paulomycin A to B is 1.41. Such ratios were determined for several samples and showed surprisingly good agreement with liquid chromatographic determinations.

The Structure of Paulomycins $A_{2}, C, D, E$ and F

The structures of paulomycins $\mathrm{A}$ and $\mathrm{B}$ have been reported by WILEY and his co-workers ${ }^{3)}$ and are shown in Fig. 6. The nucleus of the paulomycin molecule consists of two ring systems designated A and B. The maximum at $320 \mathrm{~nm}$ in the UV spectra of paulomycins arise from the chromophoric 
Table 2. Chemical shifts observed in the ${ }^{13} \mathrm{C}$ NMR spectra of paulomycins $\mathrm{A}, \mathrm{A}_{2}, \mathrm{~B}, \mathrm{C}, \mathrm{D}, \mathrm{E}$ and $\mathrm{F}$.

\begin{tabular}{|c|c|c|c|c|c|c|c|}
\hline \multirow{2}{*}{$\begin{array}{l}\text { Carbon } \\
\text { No. }^{2}\end{array}$} & \multicolumn{7}{|c|}{${ }^{13} \mathrm{C}$ NMR chemical shift of paulomycins, $\delta^{b}$ (multiplicity) } \\
\hline & A & $\mathrm{A}_{2}$ & B & $\mathrm{C}$ & D & $\mathrm{E}$ & $\mathrm{F}$ \\
\hline$C-1$ & $169.35(s)$ & $169.96(\mathrm{~s})$ & $169.35(\mathrm{~s})$ & $169.24(\mathrm{~s})$ & $169.11(\mathrm{~s})$ & $169.95(\mathrm{~s})$ & $169.10(\mathrm{~s})$ \\
\hline $\mathrm{C}-2$ & $100.72(\mathrm{~s})$ & $99.69(\mathrm{~s})$ & $100.14(\mathrm{~s})$ & $100.09(\mathrm{~s})$ & $99.92(\mathrm{~s})$ & $100.60(\mathrm{~s})$ & $100.05(\mathrm{~s})$ \\
\hline$C-3$ & $159.37(\mathrm{~s})$ & $160.04(\mathrm{~s})$ & $159.36(\mathrm{~s})$ & $158.07(\mathrm{~s})$ & $157.98(\mathrm{~s})$ & $159.78(\mathrm{~s})$ & $158.90(\mathrm{~s})$ \\
\hline $\mathrm{C}-4$ & $198.50(\mathrm{~s})$ & $198.98(\mathrm{~s})$ & $198.37(\mathrm{~s})$ & $197.44(\mathrm{~s})$ & $197.34(\mathrm{~s})$ & $199.00(\mathrm{~s})$ & $198.94(\mathrm{~s})$ \\
\hline C-5 & $48.01(t)$ & $48.62(\mathrm{t})$ & $47.95(\mathrm{t})$ & $47.81(t)$ & $47.64(\mathrm{t})$ & $48.88(\mathrm{t})$ & $48.35(t)$ \\
\hline $\mathrm{C}-6$ & $78.20(\mathrm{~s})$ & $78.90(\mathrm{~s})$ & $78.14(\mathrm{~s})$ & $78.74(\mathrm{~s})$ & $78.47(\mathrm{~s})$ & $78.81(\mathrm{~s})$ & $78.69(\mathrm{~s})$ \\
\hline $\mathrm{C}-7$ & $188.39(\mathrm{~s})$ & $189.03(\mathrm{~s})$ & $188.40(\mathrm{~s})$ & $187.78(\mathrm{~s})$ & $187.64(\mathrm{~s})$ & $189.11(\mathrm{~s})$ & $189.14(\mathrm{~s})$ \\
\hline $\mathrm{C}-8$ & $78.26(d)$ & $78.45(d)$ & $78.14(\mathrm{~d})$ & $78.63(d)$ & 78.47 (d) & $78.68(\mathrm{~d})$ & $78.59(\mathrm{~d})$ \\
\hline C-9 & $69.20(\mathrm{~d})$ & $70.05(d)$ & $69.28(\mathrm{~d})$ & $69.09(\mathrm{~d})$ & $68.95(\mathrm{~d})$ & $70.01(d)$ & $69.87(\mathrm{~d})$ \\
\hline$C-10$ & 76.18 (d) & 76.49 (d) & 75.91 (d) & $77.67(\mathrm{~d})$ & $77.10(\mathrm{~d})$ & 77.01 (d) & $76.48(d)$ \\
\hline $\mathrm{C}-11$ & $70.73(\mathrm{~d})$ & $71.45(\mathrm{~d})$ & $70.71(\mathrm{~d})$ & $71.18(\mathrm{~d})$ & $71.33(\mathrm{~d})$ & 71.48 (d) & 71.76 (d) \\
\hline $\mathrm{C}-12$ & 72.29 (d) & $72.94(\mathrm{~d})$ & $72.21(\mathrm{~d})$ & $72.45(\mathrm{~d})$ & $72.25(\mathrm{~d})$ & $72.82(\mathrm{~d})$ & $72.76(d)$ \\
\hline C-13 & $62.30(t)$ & $62.68(\mathrm{t})$ & $62.23(\mathrm{t})$ & $61.77(\mathrm{t})$ & $61.67(\mathrm{t})$ & $62.82(\mathrm{t})$ & $62.64(t)$ \\
\hline$C-1^{\prime}$ & 99.04 (d) & 99.48 (d) & $98.94(\mathrm{~d})$ & $100.02(\mathrm{~d})$ & $98.51(\mathrm{~d})$ & 99.55 (d) & 99.21 (d) \\
\hline $\mathrm{C}-2^{\prime}$ & $30.56(t)$ & $30.56(t)$ & $30.33(t)$ & $30.56(\mathrm{t})$ & $30.39(t)$ & $29.66(\mathrm{t})$ & $27.41(t)$ \\
\hline$C-3^{\prime}$ & 74.43 (d) & 74.98 (d) & 74.38 (d) & $76.40(\mathrm{~d})$ & $74.43(\mathrm{~d})$ & $76.20(\mathrm{~d})$ & $75.82(\mathrm{~d})$ \\
\hline C- $4^{\prime}$ & $73.62(\mathrm{~s})$ & $74.19(\mathrm{~s})$ & $73.66(\mathrm{~s})$ & $73.36(\mathrm{~s})$ & $73.17(\mathrm{~s})$ & $82.83(\mathrm{~s})$ & $74.60(\mathrm{~s})$ \\
\hline$C-5^{\prime}$ & $67.18(\mathrm{~d})$ & $68.30(\mathrm{~d})$ & $67.65(d)$ & $68.85(d)$ & 68.70 (d) & $69.08(\mathrm{~d})$ & $68.78(\mathrm{~d})$ \\
\hline $\mathrm{C}-6^{\prime}$ & $15.28(q)^{\mathrm{c}}$ & $15.82(q)^{\mathrm{c}}$ & $15.23(\mathrm{q})^{\mathrm{c}}$ & $15.17(\mathrm{q})^{\mathrm{c}}$ & $14.94(\mathrm{q})^{\mathrm{c}}$ & $14.71(\mathrm{q})$ & $14.70(q)$ \\
\hline C-7' & $69.93(\mathrm{~d})$ & 70.74 (d) & $69.96(\mathrm{~d})$ & $69.64(\mathrm{~d})$ & $69.58(\mathrm{~d})$ & $212.07(\mathrm{~s})$ & $71.46(\mathrm{~d})$ \\
\hline C-8' & $15.39(\mathrm{q})^{\mathrm{c}}$ & $16.12(q)^{\mathrm{e}}$ & $15.44(\mathrm{q})^{\mathrm{e}}$ & $15.56(\mathrm{q})^{\mathrm{c}}$ & $15.56(q)^{c}$ & $27.17(q)$ & $19.17(\mathrm{q})$ \\
\hline $3^{\prime}-\mathrm{OCH}_{3}$ & $56.62(\mathrm{q})$ & $57.16(q)$ & $56.59(\mathrm{q})$ & $57.76(q)$ & $52.57(q)$ & $56.50(\mathrm{q})$ & $55.81(\mathrm{q})$ \\
\hline $\mathrm{C}-1^{\prime \prime}$ & $160.25(\mathrm{~s})$ & $160.90(\mathrm{~s})$ & $160.25(\mathrm{~s})$ & $160.27(\mathrm{~s})$ & $160.14(\mathrm{~s})$ & $160.89(\mathrm{~s})$ & $160.89(\mathrm{~s})$ \\
\hline $\mathrm{C}-2^{\prime \prime}$ & $123.36(\mathrm{~s})$ & $124.01(\mathrm{~s})$ & $123.32(\mathrm{~s})$ & $123.06(\mathrm{~s})$ & $122.85(\mathrm{~s})$ & $123.95(\mathrm{~s})$ & $123.88(\mathrm{~s})$ \\
\hline$C-3^{\prime \prime}$ & $136.64(\mathrm{~d})$ & $137.26(\mathrm{~d})$ & $136.66(\mathrm{~d})$ & $136.56(\mathrm{~d})$ & 136.41 (d) & 137.35 (d) & $137.40(\mathrm{~d})$ \\
\hline $\mathrm{C}-4^{\prime \prime}$ & $14.11(q)$ & $14.70(q)$ & $14.13(q)$ & $14.70(q)$ & $14.55(\mathrm{q})$ & $14.31(q)$ & $14.01(q)$ \\
\hline $\mathrm{C}-5^{\prime \prime}$ & $142.64(\mathrm{~s})$ & $142.70(\mathrm{~s})$ & $142.54(\mathrm{~s})$ & $143.10(\mathrm{~s})$ & $143.05(\mathrm{~s})$ & $142.85(\mathrm{~s})$ & $143.10(\mathrm{~s})$ \\
\hline $\mathrm{C}-1^{\prime \prime \prime}$ & $175.15(\mathrm{~s})$ & $172.53(\mathrm{~s})$ & $175.71(\mathrm{~s})$ & $173.49(\mathrm{~s})$ & $170.23(\mathrm{~s})^{\mathrm{d}, \mathrm{e}}$ & e $\quad-$ & - \\
\hline $\mathrm{C}-2^{\prime \prime \prime}$ & 41.51 (d) & $44.08(\mathrm{t})$ & $34.15(\mathrm{~d})$ & $27.96(t)$ & $21.16(\mathrm{q})^{\mathrm{d}}$ & - & - \\
\hline$C-3^{\prime \prime \prime}$ & $26.65(\mathrm{t})$ & 26.34 (d) & $18.77(\mathrm{q})^{\mathrm{e}}$ & $9.15(q)$ & -- & - & 一 \\
\hline $\mathrm{C}-4^{\prime \prime \prime}$ & $11.39(\mathrm{q})$ & $22.71(\mathrm{q})^{\mathrm{e}}$ & $18.93(\mathrm{q})^{\circ}$ & - & - & - & - \\
\hline C-5"' & $16.73(q)$ & $22.63(\mathrm{q})^{\mathrm{e}}$ & - & - & - & - & - \\
\hline $\mathrm{C}-1^{\prime \prime \prime \prime}$ & $170.18(\mathrm{~s})$ & $170.75(\mathrm{~s})$ & $170.18(\mathrm{~s})$ & $170.77(\mathrm{~s})$ & $170.67(\mathrm{~s})^{\mathrm{e}}$ & $170.76(\mathrm{~s})$ & $169.10(\mathrm{~s})$ \\
\hline $\mathrm{C}-2^{\prime \prime \prime \prime}$ & $19.99(\mathrm{q})$ & $20.60(q)$ & $19.98(q)$ & $20.71(q)$ & $20.56(q)^{d}$ & $20.60(q)$ & $20.57(q)$ \\
\hline
\end{tabular}

a For numbering of carbons, see Fig. 6.

b Relative to TMS.

$e, a, e$ Assignments are interchangeable.

system in ring A. Any structural change in ring A like dehydration of the tertiary hydroxyl at C-6 or reduction of the ketonic functions at C-4 and/or C-7 results in loss of the $320 \mathrm{~nm}$ UV maximum. Ring B is a poly-substituted tetrahydropyrane system. An eight carbon branched sugar, named paulomycose, is linked glycosidically to the C-10 hydroxyl group of ring B. This sugar which contains a methoxy group is esterified by 2-methylbutyric acid in paulomycin $\mathrm{A}$ and by isobutyric acid in paulomycin B. An $\alpha, \beta$-unsaturated acid moiety is esterified to the hydroxyl at C-11 of ring B. This acid, named paulic acid, contains an isothiocyanate group which is the most characteristic chemical feature of paulomycins A and B and is responsible for the intense IR absorption at $2043 \mathrm{~cm}^{-1}$. The unsaturated system of paulic acid is responsible for the UV maximum at $276 \mathrm{~nm}$. Removal of this moiety from paulomycin $\mathrm{A}$ or $\mathrm{B}$ results in the formation of paulomenol $\mathrm{A}$ or $\mathrm{B}^{\text {3) }}$ which do not show UV 
Table 3. ${ }^{1} \mathrm{H}$ NMR chemical shifts of selected groups of paulomycins $A, A_{2}, B, C, D, E$ and F.

\begin{tabular}{|c|c|c|c|c|c|c|c|}
\hline \multirow{2}{*}{$\begin{array}{l}\text { Functional } \\
\text { groups }^{2}\end{array}$} & \multicolumn{7}{|c|}{${ }^{1} \mathrm{H}$ NMR chemical shift of paulomycins, $\delta$ (multiplicity) } \\
\hline & $A^{b}$ & $\mathrm{~A}_{2}{ }^{\mathrm{b}}$ & $\mathbb{B}^{b}$ & $\mathrm{C}^{\mathrm{c}}$ & $D^{e}$ & $E^{b}$ & $F^{b}$ \\
\hline $5^{\prime \prime \prime}-\mathrm{H}_{3}$ & $1.17(3 \mathrm{H}, \mathrm{d})$ & $0.99(3 \mathrm{H}, \mathrm{d})$ & - & - & - & - & - \\
\hline $4_{4}^{\prime \prime \prime}-\mathrm{H}_{3}$ & $0.94(3 \mathrm{H}, \mathrm{t})$ & $0.98(3 \mathrm{H}, \mathrm{d})$ & $1.19(3 \mathrm{H}, \mathrm{d})$ & - & - & - & - \\
\hline $3^{\prime \prime \prime}-\mathrm{H}_{3}$ & - & - & $1.17(3 \mathrm{H}, \mathrm{d})$ & $1.20(3 \mathrm{H}, \mathrm{t})$ & - & - & - \\
\hline $2^{\prime \prime \prime}-\mathrm{H}_{3}$ & - & - & - & - & $2.15(3 \mathrm{H}, \mathrm{s})$ & -- & - \\
\hline $8^{\prime}-\mathrm{H}_{3}$ & $1.27(3 \mathrm{H}, \mathrm{d})$ & $1.23(3 \mathrm{H}, \mathrm{d})$ & $1.28(3 \mathrm{H}, \mathrm{d})$ & $1.30(3 \mathrm{H}, \mathrm{d})$ & $1.35(3 \mathrm{H}, \mathrm{d})$ & $2.24(3 \mathrm{H}, \mathrm{s})$ & $1.23(3 \mathrm{H}, \mathrm{d})$ \\
\hline $6^{\prime}-\mathrm{H}_{3}$ & $1.22(3 \mathrm{H}, \mathrm{d})$ & $1.20(3 \mathrm{H}, \mathrm{d})$ & $1.19(3 \mathrm{H}, \mathrm{d})$ & $1.24(3 \mathrm{H}, \mathrm{d})$ & $1.33(3 \mathrm{H}, \mathrm{d})$ & $0.94(3 \mathrm{H}, \mathrm{d})$ & $1.08(3 \mathrm{H}, \mathrm{d})$ \\
\hline $4^{\prime \prime}-\mathrm{H}_{3}$ & $1.97(3 \mathrm{H}, \mathrm{d})$ & $1.94(3 \mathrm{H}, \mathrm{d})$ & $1.97(3 \mathrm{H}, \mathrm{d})$ & $1.96(3 \mathrm{H}, \mathrm{d})$ & $1.97(3 \mathrm{H}, \mathrm{d})$ & $1.94(3 \mathrm{H}, \mathrm{d})$ & $1.94(3 \mathrm{H}, \mathrm{d})$ \\
\hline $3^{\prime \prime}-\mathrm{H}$ & $6.83(1 \mathrm{H}, \mathrm{q})$ & $6.83(1 \mathrm{H}, \mathrm{q})$ & $6.88(1 \mathrm{H}, \mathrm{q})$ & $6.77(1 \mathrm{H}, \mathrm{q})$ & $6.81(1 \mathrm{H}, \mathrm{q})$ & $6.84(1 \mathrm{H}, \mathrm{q})$ & $6.84(1 \mathrm{H}, \mathrm{q})$ \\
\hline $2^{\prime \prime \prime \prime}-\mathrm{H}_{3}$ & $1.98(3 \mathrm{H}, \mathrm{s})$ & $1.98(3 \mathrm{H}, \mathrm{s})$ & $2.02(3 \mathrm{H}, \mathrm{s})$ & $2.05(3 \mathrm{H}, \mathrm{s})$ & $2.10(3 \mathrm{H}, \mathrm{s})$ & $1.98(3 \mathrm{H}, \mathrm{s})$ & $1.98(3 \mathrm{H}, \mathrm{s})$ \\
\hline $3^{\prime}-\mathrm{OCH}_{3}$ & $3.33(3 \mathrm{H}, \mathrm{s})$ & $3.34(3 \mathrm{H}, \mathrm{s})$ & $3.33(3 \mathrm{H}, \mathrm{s})$ & $3.43(3 \mathrm{H}, \mathrm{s})$ & $3.47(3 \mathrm{H}, \mathrm{s})$ & $3.23(3 \mathrm{H}, \mathrm{s})$ & $3.35(3 \mathrm{H}, \mathrm{s})$ \\
\hline
\end{tabular}

\& For group designation see Fig. 6

b Acetone- $d_{6}$ was used as solvent.

- $\mathrm{CDCl}_{3}$ was used as solvent. 
Table 4. Common ions observed in the negative ion FAB-MS of paulomycins.

\begin{tabular}{rrrlrc}
\hline$m / z$ & $\begin{array}{c}\text { Measured } \\
\text { mass }^{2}\end{array}$ & Theory & \multicolumn{1}{c}{ For } & $\Delta(\mathrm{mmu})$ & Assignment $^{\mathrm{b}}$ \\
\hline 58 & 57.9756 & 57.9751 & $\mathrm{CNS}$ & 0.5 & I \\
98 & 98.0075 & 98.0064 & $\mathrm{C}_{4} \mathrm{H}_{4} \mathrm{NS}_{5}$ & 1.1 & II \\
110 & 110.0235 & 110.0242 & $\mathrm{C}_{5} \mathrm{H}_{4} \mathrm{NO}_{2}$ & -0.7 & III \\
142 & 141.9975 & 141.9963 & $\mathrm{C}_{5} \mathrm{H}_{4} \mathrm{NO}_{2} \mathrm{~S}$ & 1.2 & IV \\
151 & 151.0269 & 151.0269 & $\mathrm{C}_{7} \mathrm{H}_{5} \mathrm{NO}_{3}$ & 0.0 & VI \\
167 & 167.0214 & 167.0219 & $\mathrm{C}_{7} \mathrm{H}_{5} \mathrm{NO}_{4}$ & -0.5 & VII \\
167 & 166.9970 & 166.9980 & $\mathrm{C}_{7} \mathrm{H}_{3} \mathrm{O}_{5}$ & -1.0 & VIII \\
183 & 183.0355 & 183.0354 & $\mathrm{C}_{8} \mathrm{H}_{8} \mathrm{NO}_{2} \mathrm{~S}$ & 0.1 & V \\
195 & 195.0165 & 195.0168 & $\mathrm{C}_{5} \mathrm{H}_{5} \mathrm{NO}_{5}$ & -0.3 & IX \\
355 & 355.0941 & 355.0903 & $\mathrm{C}_{25} \mathrm{H}_{17} \mathrm{NO}_{3}$ & 3.8 & X \\
\hline
\end{tabular}

a High resolution data were obtained on paulomycins $\mathbf{A}$ and $\mathbf{B}$ only.

b For structural assignments, see Fig. 7.

Fig. 6 .
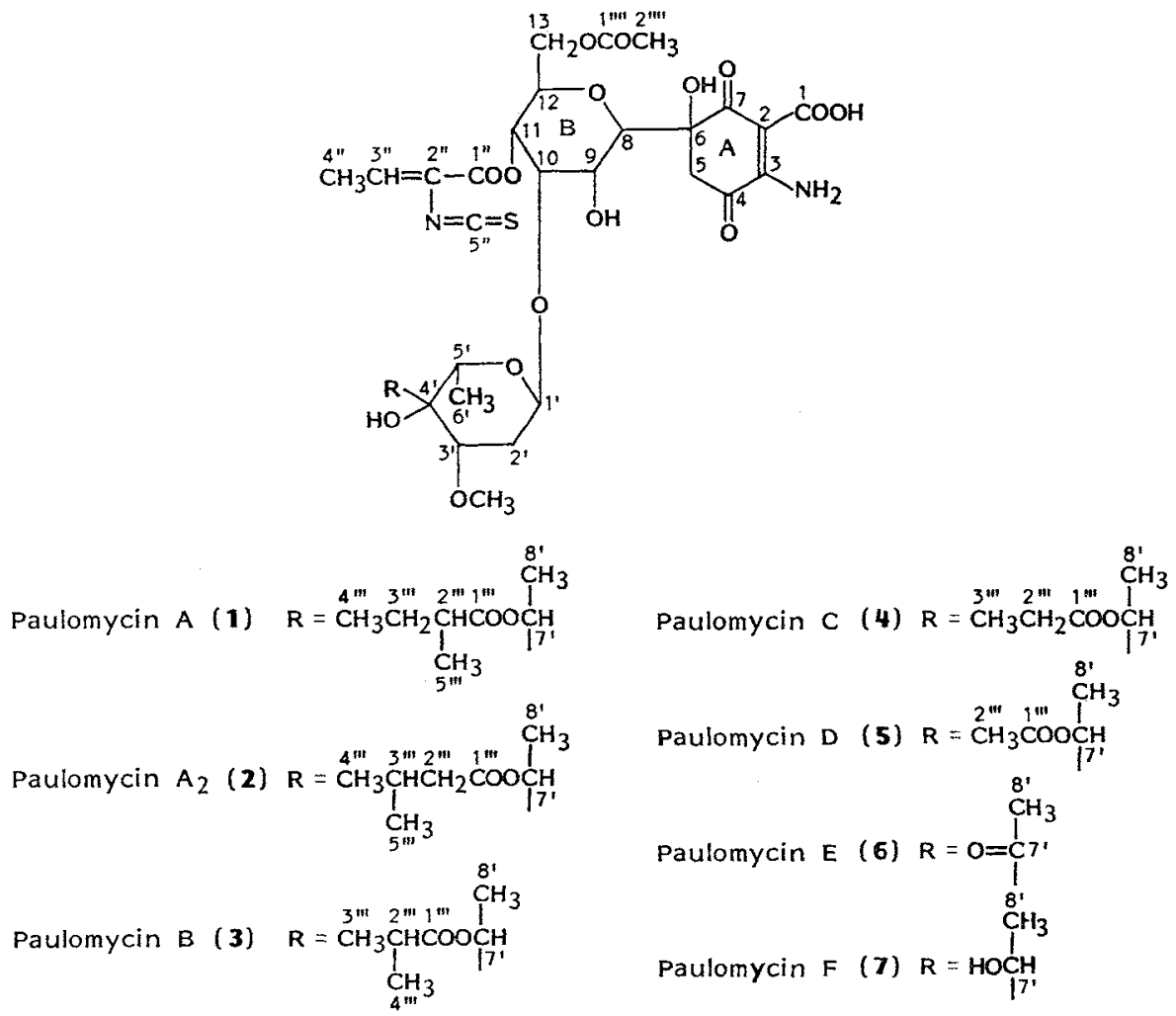

absorption at this wavelength.

Paulomycins $A_{2}, C, D, E$ and $F$ have UV and IR spectra (Table 1) very similar to those of paulomycins $A$ and $B$. This indicates the presence of the intact ring $A$ and the paulic acid fragment in these molecules. Comparison of the ${ }^{1} \mathrm{H}$ and ${ }^{18} \mathrm{C}$ NMR spectra of paulomycins $\mathrm{A}_{2}, \mathrm{C}, \mathrm{D}, \mathrm{E}$ and $\mathrm{F}$ (Tables 2 and 3) support this conclusion. Furthermore, MS data (Table 4 and Fig. 7) indicate that all paulomycins $\left(A, A_{2}, B, C, D, E\right.$ and $F$ ) have identical fragmentation patterns at the low mass 
Fig. 7. Ion-fragments $(m / z)$ observed in the negative ion high resolution FAB-MS of paulomycins.

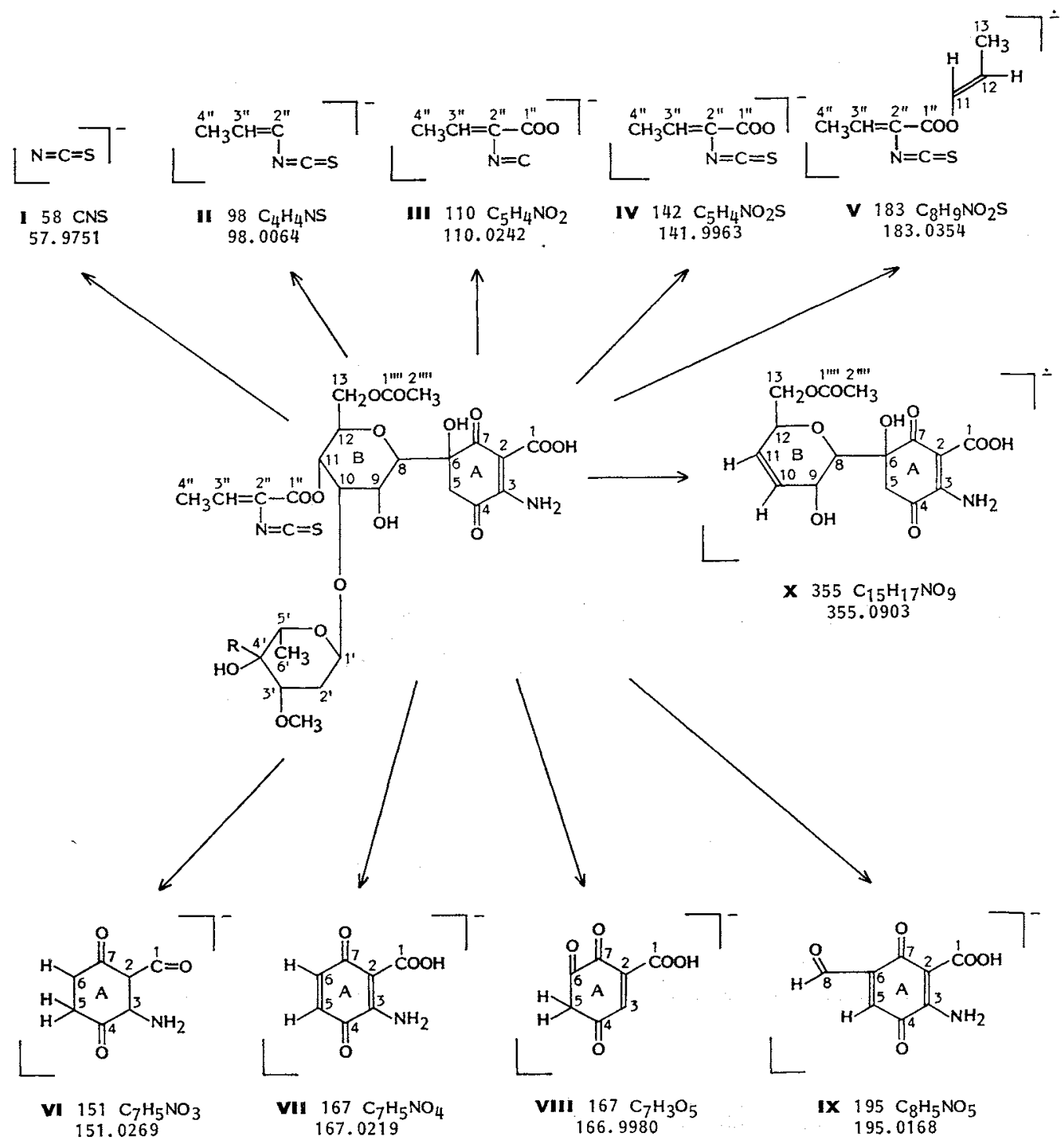

area $(m / z<360)$ indicating that moiety 8 is a common structural feature of all paulomycins.

The structural differences between paulomycins are located in the esterified paulomycose part of the paulomycin molecule. Paulomycin $A_{2}$ has a molecular composition (Table 1) identical to that of paulomycin A. ${ }^{13} \mathrm{C}$ NMR spectra (Table 2) indicate that both antibiotics contain (1) paulomycose esterified to a five carbon acid which in the case of paulomycin A (1) is 2- 
Table 5. Antibacterial spectra ${ }^{a}$ of paulomycins A, A $, B, C, D, E$ and F.

\begin{tabular}{|c|c|c|c|c|c|c|c|c|}
\hline \multirow{2}{*}{ Organism } & \multirow{2}{*}{ UC No. } & \multicolumn{7}{|c|}{$\mathrm{MIC}(\mu \mathrm{g} / \mathrm{ml})^{\mathrm{b}}$ of paulomycins } \\
\hline & & A & $\mathrm{A}_{2}$ & $\mathrm{~B}$ & $\mathrm{C}$ & $\mathrm{D}$ & $\mathrm{E}$ & $\mathrm{F}$ \\
\hline Staphyloccocus aureus & 9218 & 0.06 & 0.06 & 0.06 & 0.25 & 0.25 & 0.25 & 1.00 \\
\hline S. aureus & 3665 & 0.125 & 0.25 & 0.125 & 0.50 & 0.50 & 1.00 & 2.00 \\
\hline S. aureus & 6685 & 0.125 & 0.125 & 0.125 & 0.25 & 0.50 & 0.50 & 2.00 \\
\hline S. aureus & 9213 & 0.125 & 0.125 & 0.125 & 0.25 & 1.00 & 0.50 & 2.00 \\
\hline S. epidermidis & 30031 & 0.06 & 0.125 & 0.06 & 0.25 & 0.25 & 0.50 & 0.50 \\
\hline Streptococcus faecalis & 694 & 0.50 & 1.00 & 0.50 & 1.00 & 16.00 & 4.00 & 32.00 \\
\hline S. pneumoniae & 41 & 0.06 & 0.06 & 0.06 & 0.06 & 0.125 & 0.06 & 0.50 \\
\hline S. pyogenes & 152 & 0.06 & - & -. & - & 0.125 & 0.25 & 0.25 \\
\hline Citrobacter freundii & 3507 & $>64$ & 一 & - & - & $>64$ & $>64$ & $>64$ \\
\hline Enterobacter cloacae & 9381 & $>64$ & - & - & - & $>64$ & $>64$ & $>64$ \\
\hline E. cloacae & 9382 & $>64$ & - & - & - & $>64$ & $>64$ & $>64$ \\
\hline Escherichia coli & 9379 & $>64$ & 一 & - & - & $>64$ & $>64$ & $>64$ \\
\hline E. coli & 9380 & $>64$ & - & - & - & $>64$ & $>64$ & $>64$ \\
\hline E. coli & 9451 & $>64$ & - & - & - & $>64$ & $>64$ & $>64$ \\
\hline Klebsiella oxytoca & 9383 & $>64$ & 一 & - & - & $>64$ & $>64$ & $>64$ \\
\hline K. oxytoca & 9384 & $>64$ & - & - & - & $>64$ & $>64$ & $>64$ \\
\hline K. pneumoniae & 58 & $>64$ & - & -- & $\ldots$ & $>64$ & $>64$ & $>64$ \\
\hline Proteus vulgaris & 9679 & $>64$ & - & - & - & $>64$ & $>64$ & $>64$ \\
\hline Serratia marcescens & 6888 & $>64$ & - & - & - & $>64$ & $>64$ & $>64$ \\
\hline Pseudomonas aeruginosa & 231 & $>64$ & - & - & - & $>64$ & $>64$ & $>64$ \\
\hline P. aeruginosa & 9191 & $>64$ & - & - & -- & $>64$ & $>64$ & $>64$ \\
\hline
\end{tabular}

a In vitro antibacterial data were provided by Mr. G. E. ZURENKo and B. H. YAGI of The Upjohn Company.

b Test method: Agar dilution, $\mathrm{pH} 6.0$. 
methylbutyric acid ${ }^{32, t}$ while paulomycin $A_{2}$ (2) contains 3-methylbutyric acid. ${ }^{*}$

Paulomycins A, B, C and D comprise a homologous series of compounds (Table 1) differing from each other by a $\mathrm{CH}_{2}$ group. ${ }^{13} \mathrm{C}$ and ${ }^{1} \mathrm{H}$ NMR spectra (Tables 2 and 3 ) indicate that all four antibiotics contain paulomycose and they differ in the nature of the acid esterified to the hydroxyl at C-7' as shown in Fig. 6. Paulomycins A (1) and B (3) are esters of 2-methylbutyric and isobutyric acids, ${ }^{2)}$ while paulomycins $C(4)$ and $D(5)$ are esterified to propionic acid and acetic acid, respectively.

The molecular weight and composition of paulomycin $F$ differ from that of paulomycin $D$ by 42 daltons and $\mathrm{C}_{2} \mathrm{H}_{2} \mathrm{O}$, respectively. This suggests that in paulomycin $\mathrm{F}$ the paulomycose moiety is not esterified at $C-7^{\prime}$, as is the case with paulomycins $\mathrm{A}, \mathrm{A}_{2}, \mathrm{~B}, \mathrm{C}$ and $\mathrm{D}$, and therefore its structure is presented by 7 (Fig. 6). This conclusion is in agreement with ${ }^{13} \mathrm{C}$ and ${ }^{1} \mathrm{H}$ NMR data. (Tables 2 and 3).

Paulomycin $\mathrm{E}$ has two hydrogens less than paulomycin $\mathrm{F}$. This suggests oxidation $(>\mathrm{CHOH} \rightarrow$ $>\mathrm{C}=\mathrm{O}$ ) at $\mathrm{C}-7^{\prime}$ of paulomycose. Paulomycin $\mathrm{F}$ contains two $\mathrm{CH}_{3} \mathrm{CHO}$ groups in the sugar part of

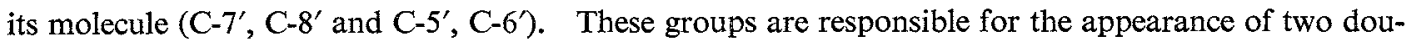
blets at $\delta 1.08(3 \mathrm{H})$ and $1.23(3 \mathrm{H})$ in the ${ }^{1} \mathrm{H}$ NMR spectrum of this antibiotic. The ${ }^{1} \mathrm{H}$ NMR spectrum of paulomycin $\mathrm{E}$ contains only one doublet in this area $(\delta 0.94,3 \mathrm{H})$ which is assigned to $\mathrm{C}-6^{\prime}$ of the sugar part of paulomycin E. The $\stackrel{8^{\prime}}{\mathrm{C}} \mathrm{H}_{3} \stackrel{7^{\prime}}{\mathrm{H}} \mathrm{HOH}$ group has been oxidized to $\stackrel{\mathrm{g}^{\prime}}{\mathrm{C}} \mathrm{H}_{3} \stackrel{\mathrm{f}^{\prime}}{\mathrm{C}}=\mathrm{O}$ and this methyl keto-group is responsible for the singlet at $\delta 2.24(3 \mathrm{H})$ in the ${ }^{1} \mathrm{H}$ NMR spectrum of paulomycin E. This conclusion agrees with ${ }^{13} \mathrm{C}$ NMR data. Absorptions at $\delta 74.60$ (s), 71.46 (d) and 19.17 (q) assigned to $\mathrm{C}-4^{\prime}, \mathrm{C}-7^{\prime}$ and $\mathrm{C}-8^{\prime}$ of paulomycin $\mathrm{F}$ have been shifted to 82.83 (s), 212.07 (s) and 27.17 (q) in the ${ }^{13} \mathrm{C}$ NMR spectrum of paulomycin $\mathrm{E}$ as expected for the following transformation. The structure of paulomycin $E$ is therefore represented by 6 .

\section{Biological Properties of Paulomycins $\mathrm{A}_{2}, \mathrm{C}, \mathrm{D}, \mathrm{E}$ and $\mathrm{F}$}

The in vitro antibacterial spectrum of paulomycins $\mathrm{A}, \mathrm{A}_{2}, \mathrm{~B}, \mathrm{C}, \mathrm{D}, \mathrm{E}$ and $\mathrm{F}$ against selected organisms is presented in Table 5. All paulomycins are mainly active against Gram-positive organisms especially Staphyloccoccus aureus including strains resistant to penicillin, streptomycin, neomycin, macrolide and lincosaminide antibiotics. Paulomycins $\mathrm{A}$ and $\mathrm{A}_{2}$ were the most active followed in order of decreasing activity, by paulomycins B, C, D, E and F. Further biological evaluation of selected paulomycins is underway.

Relation of Paulomycins $\mathrm{A}_{2}, \mathrm{C}, \mathrm{D}, \mathrm{E}$ and $\mathrm{F}$ to Other Antibiotics

Paulomycins $\mathrm{A}_{2}, \mathrm{C}, \mathrm{D}, \mathrm{E}$ and $\mathrm{F}$, like paulomycins $\mathrm{A}$ and $\mathrm{B}^{1)}$ have physical properties (IR, UV, elemental composition) similar to those of proceomycin $^{4)}$ and senfolomycins A and B. ${ }^{5,6)}$ Very little has been reported concerning the structure of the senfolomycins and proceomycins. Reported data ${ }^{5,8)}$ and direct TLC and HPLC comparison differentiate paulomycins $\mathrm{A}, \mathrm{B}, \mathrm{A}_{2}, \mathrm{C}$, $D, E$ and $F$ from senfolomycin A. Reported ${ }^{1} \mathrm{H}$ NMR data on senfolomycin $B^{6)}$ also dif-
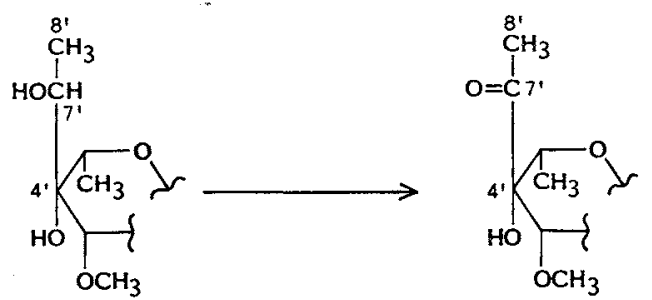

† ${ }^{13} \mathrm{C}$ NMR chemical shifts reported for 1) 2-methylbutyric acid: $\delta 183.6(\mathrm{~s}, \mathrm{C}-1), 41.2(\mathrm{~d}, \mathrm{C}-2), 26.8(\mathrm{t}, \mathrm{C}-3)$, 11.6 (q, C-4), 16.4 (q, C-5). 2) 3-Methylbutyric acid: $\delta 179.7$ (s, C-1), 43.4 (t, C-2), 25.7 (d, C-3), 22.5 (q, C-4), 22.5 (q, C-5), (Stadtler's Standard ${ }^{13} \mathrm{C}$ NMR Spectra. Spectra No. 1082 and 2843). 
ferentiates this antibiotic from the paulomycins reported to date. The paulomycins, proceomycin and senfolomycins are all characterized by the intense IR absorption at $2050 \sim 2043 \mathrm{~cm}^{-1}$ which is due to the presence of an isothiocyanate group and have identical UV spectra. They are chemically similar and make up an expanding family of antibiotics.

\section{Acknowledgment}

The authors express their appreciation to Mr. K. J. GeIPEL for technical assistance, to Mr. G. E. ZURENKo for biological testing, to Mr. J. A. BuEge for large scale extractions, and to Dr. P. F. WiLEY for valuable comments and suggestions.

\section{References}

1) Argoudelis, A. D.; T. A. Brinkley, T. F. Brodasky, J. A. Buege, H. F. Meyer \& S. A. Mizsak: Paulomycins A and B. Isolation and characterization. J. Antibiotics 35:285 294, 1982

2) Marshall, V.P.; M.S. Little \& L.E. Johnson: A new process and organism for the fermentation production of volonomycin. J. Antibiotics 34: 902 904, 1981

3) Wiley, P. F.; S. A. Mizsak, L. B. Baczynskyj, A. D. Argoudelis, D. J. Duchamp \& W. Watt: The structure and chemistry of paulomycin. J. Org. Chem. 51:2493 2499, 1986

4) Tsukiura, H.; M. OKanishi, H. Koshiyama, T. Ohmori, T. Miyaki \& H. Kawaguchi: Proceomycin, a new antibiotic. J. Antibiotics, Ser. A 17:223 229, 1964

5) Mitscher, L. A.; W. Mcrae, S. E. Devoe, A. J. Shay, W. K. Hausmann \& N. Bohonos: Senfolomycin A and B, new antibiotics. Antimicrob. Agents Chemother.-1965: 828 831, 1966

6) Devoe, S. E. \& L. A. Mrtscher (Cyanamid): Antibiotic $6950 \beta$ and method of production using Streptomyces ochrosporus. U.S. 3,377,243, Apr. 9, 1968 